\title{
Energy saving potential of natural ventilation in China: The impact of ambient air pollution
}

\author{
Zheming Tong a,b,*,1, Yujiao Chen ${ }^{\mathrm{a}, \mathrm{b}, *, 1}$, Ali Malkawi ${ }^{\mathrm{a}, \mathrm{b}}$, Zhu Liu ${ }^{\mathrm{c}}$, Richard B. Freeman ${ }^{\mathrm{a}, \mathrm{d}, \mathrm{e}}$ \\ ${ }^{a}$ Center for Green Buildings and Cities, Harvard University, Cambridge, MA 02138, USA \\ ${ }^{\mathrm{b}}$ Graduate School of Design, Harvard University, Cambridge, MA 02138, USA \\ 'John F. Kennedy School of Government, Harvard University, Cambridge, MA 02138, USA \\ ${ }^{\mathrm{d}}$ Department of Economics, Harvard University, Cambridge, MA 02138, USA \\ ${ }^{\mathrm{e}}$ National Bureau of Economic Research, Cambridge, MA 02138, USA
}

\section{H I G H L I G H T S}

- Natural ventilation potential is affected largely by ambient air pollution in China.

- NV hours of 76 Chinese cities based on weather and ambient air quality are estimated.

- Cooling energy savings and carbon reductions of 35 major Chinese cities are estimated.

- $8-78 \%$ of the cooling energy usage can be potentially reduced by NV.

- Our findings provide guidelines to improve energy policies in China.

\section{A R T I C L E I N F O}

\section{Article history:}

Received 10 May 2016

Received in revised form 1 July 2016

Accepted 9 July 2016

\section{Keywords:}

Natural ventilation

Energy saving

China

Air pollution

AQI

$\mathrm{CO}_{2}$ emission

\begin{abstract}
A B S T R A C T
Natural ventilation (NV) is a key sustainable solution for reducing the energy use in buildings, improving thermal comfort, and maintaining a healthy indoor environment. However, the energy savings and environmental benefits are affected greatly by ambient air pollution in China. Here we estimate the NV potential of all major Chinese cities based on weather, ambient air quality, building configuration, and newly constructed square footage of office buildings in the year of 2015. In general, little NV potential is observed in northern China during the winter and southern China during the summer. Kunming located in the Southwest China is the most weather-favorable city for natural ventilation, and reveals almost no loss due to air pollution. Building Energy Simulation (BES) is conducted to estimate the energy savings of natural ventilation in which ambient air pollution and total square footage at each city must be taken into account. Beijing, the capital city, displays limited per-square-meter saving potential due to the unfavorable weather and air quality for natural ventilation, but its largest total square footage of office buildings makes it become the city with the greatest energy saving opportunity in China. Our analysis shows that the aggregated energy savings potential of office buildings at 35 major Chinese cities is $112 \mathrm{GWh}$ in 2015, even after allowing for a $43 \mathrm{GWh}$ loss due to China's serious air pollution issue especially in North China. $8-78 \%$ of the cooling energy consumption can be potentially reduced by natural ventilation depending on local weather and air quality. The findings here provide guidelines for improving current energy and environmental policies in China, and a direction for reforming building codes.
\end{abstract}

(c) 2016 Elsevier Ltd. All rights reserved.

\footnotetext{
* Corresponding authors at: Center for Green Buildings and Cities, Harvard University, Cambridge, MA 02138, USA.

E-mail addresses: ztong@gsd.harvard.edu (Z. Tong), ychen@gsd.harvard.edu (Y. Chen).

${ }^{1}$ These authors contributed equally to this work.
}

\section{Introduction}

China has experienced rapid economic expansion and industrial development for the last two decades, making it the engine of the world's economic growth. According to the International Monetary Fund IMF [1], China reached \$17.6 trillion purchasing-poweradjusted GDP in 2014 and became the country with the largest GDP in the world, surpassing the United States (\$17.4 trillion). As 
a result of this rapid growth, energy consumption and associated $\mathrm{CO}_{2}$ emissions have increased dramatically [2-4].

The building sector is a critical contributor to China's energy consumption, and the sector's life-cycle energy consumption accounts for over $40 \%$ of China's total energy use [5,6]. HVAC systems that heat, cool, and ventilate buildings comprise approximately $47 \%$ of operational energy consumption in buildings across China [7]. Many advanced technologies have been developed to achieve high building energy efficiency [8-16]. Natural ventilation that supplies and removes air to and from an indoor space without the use of mechanical systems shows great potential to reduce energy consumption and the cost of the HVAC system [17]. Europe and the North America already pay a great attention to advanced NV technologies such as wind tower, solar chimney, and automated window controls [18-23], which exhibits a substantial reduction in cooling energy usage by as much as $40-50 \%$ in some cities [24-26]. However, the operation of NV in urban environment is affected by a number of factors such as outdoor ambient air pollution and noise [27-31]. In particular, outdoor ambient air pollution is an urgent challenge facing China's development [32]. A large number of cities in China suffer from the degradation of air quality and associated health risks, such as respiratory symptoms and cardiovascular diseases [33-38]. In the year of $2014 / 2015$, only 25 out of 190 Chinese cities were able to meet the National Ambient Air Quality Standards of China [39]. The impact of air pollution on NV operation is clearly significant. A few studies estimated the natural ventilation potential at several representative cities in China with simplified building models [4042 ], but did not consider the pressing impact of air pollution.

Here we first estimate the NV potential in terms of NV hours of 76 Chinese cities based on local weather and ambient air pollution data from Aug. 2014 to Aug. 2015. The NV potential in terms of energy savings from cooling, and the reductions in carbon dioxide emission for 35 major cities are then estimated using a Building Energy Simulation (BES) program and available square footage of newly constructed office building at each city. To our knowledge, this is the first study to quantify the energy savings potential of natural ventilation in China considering the impact of ambient air pollution.

\section{Methodology}

\subsection{Climate data}

The climate in China varies from region to region due to the massive expanse of land and complicated terrain. According to the Standard on Division of Climate Zones for Buildings [43], the country is categorized into five climate zones: Severe Cold, Cold, Hot Summer/Cold Winter (HSCW), Hot Summer/Warm Winter (HSWW), and Mild (Fig. 1). In general, the northern part of China is characterized into Severe Cold and Cold zones where space heating dominates energy use in buildings. In the central part of China, covered by HSCW zone, both space heating and cooling are required in buildings. Southern China is mostly categorized into HSWW zone where space cooling is needed in the summer. The hourly Chinese Standard Weather Data (CSWD) developed by the China Meteorological Bureau and Tsinghua University are employed for Building Energy Simulation [44].

\subsection{Air quality data}

Air quality index (AQI) is used to inform the public about levels of air pollution and associated health risks. The AQI approach is based on the maximum value of individual pollutants in China. In general, as AQI increases, a larger percentage of the population

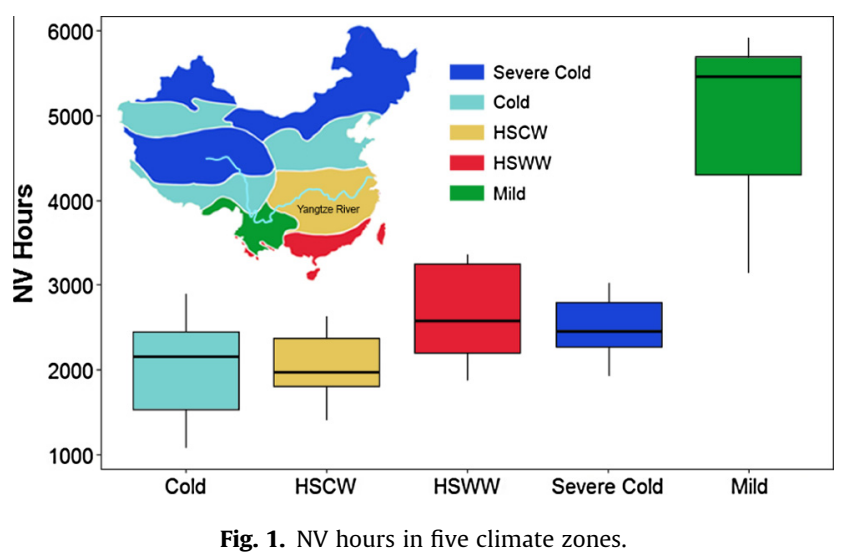

is likely to experience severe adverse health effects. In this study, hourly AQI data are downloaded from the China National Environmental Monitoring Center website (http://113.108.142.147:20035/ emcpublish/). We choose one-year data from Aug. 2014 to Aug. 2015 due to the largest available coverage of Chinese cities (76 cities). According to the health effects defined in each AQI level (Table 2), the ambient air pollution start to cause negative health effects for sensitive groups when AQI is greater than 100 [45]. The AQI threshold for allowing natural ventilation is therefore chosen at 100 .

In our analysis, the spatial variation of AQI within each city is not considered due to limited data availability. The AQI defined by Ministry of Environmental Protection of the People's Republic of China is based on the Eq. (1).

$I A Q I_{p}=\frac{I A Q I_{H i}-I A Q I_{L o}}{B P_{H i}-B P_{L o}}\left(C_{p}-B P_{L o}\right)+I A Q I_{L o}$

where IAQI ${ }_{p}$ is the index for pollutant $p ; C_{p}$ is the rounded concentration of pollutant $\mathrm{p}$; $\mathrm{BP}_{\mathrm{Hi}}$ is the breakpoint that is greater than or equal to $C_{p} ; B_{L o}$ is the breakpoint that is less than or equal to $C_{p}$; $I_{A Q I}$ is the $A Q I$ value corresponding to $B_{H}$; $I_{A Q I}$ is the $A Q I$ value corresponding to $\mathrm{BP}_{\mathrm{Lo}}$. IAQI and corresponding thresholds of each pollutant is displayed in Table 1 . The overall AQI is the maximum of the individual AQIs as shown in Eq. (2).

$A Q I=\max \left\{I A Q I_{1}, I A Q I_{2}, I A Q I_{3}, \ldots, I A Q I_{6}\right\}$

\subsection{Building energy simulation}

The per-square-meter cooling energy savings at each Chinese city is estimated using EnergyPlus, a validated and physics-based Building Energy Simulation (BES) program developed by U.S. Department of Energy [46]. A brief description of the model is presented here. The core of the model is based on fundamental heat balance principle. The energy balance on each zone is described in Eq. (3), which assumes a well-mixed indoor air temperature.

$\rho c_{p} V \frac{d T}{d t}=\sum_{i=1}^{n} h_{i} A_{i}\left(T_{i}-T_{\text {int }}\right)+\dot{Q}_{A C}+\dot{Q}_{\text {load }}+\dot{Q}_{n v}$

$\rho$ is the air density. $c_{p}$ is the specific heat of air. $V$ is the volume of the zone. $T_{i n t}$ is the indoor air temperature in $\mathrm{K}$. On the left-hand side, $\rho c_{p} V \frac{d T}{d t}$ represents the rate of energy change in the zone in the unit of $\mathrm{W}$. On the right-hand side, $\sum_{i=1}^{n} h_{i} A_{i}\left(T_{i}-T_{i n t}\right)$ denotes the convective heat transfer rate from zone surfaces in W. $\dot{Q}_{A C}$ is the cooling rate due to air conditioning in W. $\dot{Q}_{\text {load }}$ is the internal heat load in W. $\dot{Q}_{n v}$ is the heat transfer rate by ventilation (W) and equal to $\rho c_{p} \dot{V}_{n v}\left(T_{\text {int }}-T_{\text {out }}\right)$ where $\dot{V}_{n v}$ is the rate of natural ven- 
Table 1

Individual AQI and corresponding thresholds of six pollutants.

\begin{tabular}{|c|c|c|c|c|c|c|c|c|c|c|}
\hline \multirow{2}{*}{$\begin{array}{l}\text { Individual air } \\
\text { quality Index }\end{array}$} & \multirow{2}{*}{$\begin{array}{l}\text { Sulfur } \\
\text { dioxide } \\
\left(\mathrm{SO}_{2}\right) \\
\left(\mu \mathrm{g} / \mathrm{m}^{3}\right) \\
{[24 \mathrm{~h}]}\end{array}$} & \multirow{2}{*}{$\begin{array}{l}\text { Sulfur } \\
\text { dioxide } \\
\left(\mathrm{SO}_{2}\right) \\
\left(\mu \mathrm{g} / \mathrm{m}^{3}\right) \\
{[1 \mathrm{~h}]^{\mathrm{a}}}\end{array}$} & \multirow{2}{*}{$\begin{array}{l}\text { Nitrogen } \\
\text { dioxide }\left(\mathrm{NO}_{2}\right) \\
\left(\mu \mathrm{g} / \mathrm{m}^{3}\right)[24 \mathrm{~h}]\end{array}$} & \multirow{2}{*}{$\begin{array}{l}\text { Nitrogen } \\
\text { dioxide }\left(\mathrm{NO}_{2}\right) \\
\left(\mu \mathrm{g} / \mathrm{m}^{3}\right)[1 \mathrm{~h}]^{\mathrm{a}}\end{array}$} & \multirow[b]{2}{*}{$\begin{array}{l}\text { Carbon } \\
\text { Monoxide } \\
(\mathrm{CO}) \\
\left(\mathrm{mg} / \mathrm{m}^{3}\right) \\
{[24 \mathrm{~h}]}\end{array}$} & \multirow[b]{2}{*}{$\begin{array}{l}\text { Carbon } \\
\text { Monoxide } \\
(\mathrm{CO}) \\
\left(\mathrm{mg} / \mathrm{m}^{3}\right) \\
{[1 \mathrm{~h}]^{\mathrm{a}}}\end{array}$} & \multirow[b]{2}{*}{$\begin{array}{l}\text { Ozone } \\
\left(\mathrm{O}_{3}\right) \\
\left(\mu \mathrm{g} / \mathrm{m}^{3}\right) \\
{[8 \mathrm{~h}]}\end{array}$} & \multirow[b]{2}{*}{$\begin{array}{l}\text { Ozone } \\
\left(\mathrm{O}_{3}\right) \\
\left(\mu \mathrm{g} / \mathrm{m}^{3}\right) \\
{[1 \mathrm{~h}]}\end{array}$} & \multicolumn{2}{|c|}{ Particulate matter } \\
\hline & & & & & & & & & $\begin{array}{l}\text { PM } 2.5 \\
\left(\mu \mathrm{g} / \mathrm{m}^{3}\right) \\
{[24 \mathrm{~h}]}\end{array}$ & $\begin{array}{l}\text { PM } 10 \\
\left(\mu \mathrm{g} / \mathrm{m}^{3}\right) \\
{[24 \mathrm{~h}]}\end{array}$ \\
\hline 0 & 0 & 0 & 0 & 0 & 0 & 0 & 0 & 0 & 0 & 0 \\
\hline 50 & 50 & 150 & 40 & 100 & 2 & 5 & 100 & 160 & 35 & 50 \\
\hline 100 & 150 & 500 & 80 & 200 & 4 & 10 & 160 & 200 & 75 & 150 \\
\hline 150 & 475 & 650 & 180 & 700 & 14 & 35 & 215 & 300 & 115 & 250 \\
\hline 200 & 800 & 800 & 280 & 1200 & 24 & 60 & 265 & 400 & 150 & 350 \\
\hline 300 & 1600 & b & 565 & 2340 & 36 & 90 & 800 & 800 & 250 & 420 \\
\hline 400 & 2100 & b & 750 & 3090 & 48 & 120 & c & 1000 & 350 & 500 \\
\hline 500 & 2620 & b & 940 & 3840 & 60 & 150 & c & 1200 & 500 & 600 \\
\hline
\end{tabular}

a 1-h concentration of $\mathrm{SO}_{2}, \mathrm{NO}_{2}, \mathrm{CO}$ is only used for hourly report. 24-h concentration should be used in daily report.

b If 1 -h SO $\mathrm{SO}_{2}$ concentration exceeds $800 \mu \mathrm{g} / \mathrm{m}^{3}, 24-\mathrm{h}$ concentration should be used instead.

c If 8 -h $\mathrm{O}_{3}$ concentration exceeds $800 \mu \mathrm{g} / \mathrm{m}^{3}, 1$-h concentration should be used instead.

Table 2

The health categories and definitions for Air Quality Index (AQI).

\begin{tabular}{|c|c|c|}
\hline AQI & Health risk category & Meaning \\
\hline $0-50$ & Good & Air quality is considered satisfactory, and air pollution poses little or no risk \\
\hline $50-100$ & Moderate & $\begin{array}{l}\text { Air quality is acceptable; however, for some pollutants there may be a moderate health concern for a very small number of } \\
\text { people who are unusually sensitive to air pollution }\end{array}$ \\
\hline $101-150$ & $\begin{array}{l}\text { Unhealthy for } \\
\text { sensitive groups }\end{array}$ & Children, older adults, and people with lung and heart disease are likely to be affected \\
\hline $151-200$ & Unhealthy & Everyone may begin to experience health effects; members of sensitive groups may experience more serious health effects \\
\hline 201-300 & Very unhealthy & Health warnings of emergency conditions. The entire population is more likely to be affected \\
\hline $301-500$ & Hazardous & Health alert: everyone may experience more serious health effects \\
\hline
\end{tabular}

tilation $\left(\mathrm{m}^{3} / \mathrm{s}\right)$ as a function of wind speed and thermal stack effect given in Eq. (4).

$\dot{V}_{n v}=\sqrt{\left(\dot{V}_{\text {wind }}\right)^{2}+\left(\dot{V}_{\text {stack }}\right)^{2}}$

The wind-drive ventilation rate $\dot{V}_{\text {wind }}$ in $\mathrm{m}^{3} / \mathrm{s}$ is given by Eq. (5) according to ASHRAE Handbook of Fundamentals ASHRAE [47].

$\dot{V}_{\text {wind }}=C_{w} A_{\text {opening }} F_{\text {schedule }} u$

$\mathrm{u}$ is local wind speed. $A_{\text {opening }}$ is the opening area. $F_{\text {schedule }}$ is the value of ventilation schedule. $C_{w}$ is the opening effectiveness given by Eq. (6).

$C_{w}=0.55-0.25 \cdot \frac{\left|\alpha_{e f f}-\alpha_{\text {wind }}\right|}{180}$

$\left|\alpha_{e f f}-\alpha_{\text {wind }}\right|$ is the difference between effective angle of wind entrance and wind direction. This equation is a linear interpolation using values suggested in the ASHRAE handbook ASHRAE [47]. On the other hand, the ventilation rate $\left(\mathrm{m}^{3} / \mathrm{s}\right)$ due to stack effect is described in Eq. (7).

$\dot{V}_{\text {stack }}=C_{D} A_{\text {opening }} F_{\text {schedule }} \sqrt{2 g \Delta H_{N P L} \frac{\left|T_{\text {int }}-T_{\text {out }}\right|}{T_{\text {int }}}}$

$C_{D}$ is the discharge coefficient for opening shown in Eq. (8) according to ASHRAE Handbook ASHRAE [47]. $\Delta H_{N P L}$ is the height (m) from midpoint of lower opening to the neutral pressure level.

$C_{D}=0.4+0.0045\left|T_{\text {int }}-T_{\text {out }}\right|$

In our EnergyPlus model, a five-story office building with a gross floor area of $5000 \mathrm{~m}^{2}$ (1000 $\mathrm{m}^{2}$ each floor) is created based on Chinese Building Design Standard [48]. The thermal characteristics (e.g., $U$ value) of the building in each climate zone are shown in Table 3. Sensitivity study on different building configurations is presented in Section 3.3.
The percentages of different type of HVAC system installed in office buildings of major Chinese cities are unavailable. We assumed that the modeled building is served by a fan coil unit (FCU) due to its popularity in China, which consumes much less energy than the variable air volume (VAV) system, therefore suiting the energy structure in China [49]. The cooling energy consumption investigated also includes those from auxiliary systems such as fans and pumps. The overall window-to-wall ratio is set as $50 \%$ and the operable window ratio is $30 \%$. The plug load is $15 \mathrm{~W} / \mathrm{m}^{2}$ and lighting power density is $9 \mathrm{~W} / \mathrm{m}^{2}$. The fresh air rate is set as $8.3 \mathrm{~L} / \mathrm{s}$-person. The cooling and heating set-point temperatures for mechanical ventilation are $26^{\circ} \mathrm{C}$ and $20^{\circ} \mathrm{C}$, respectively. The operation schedule of HVAC system is set as 7:00-18:00 from Monday to Friday. The coefficient of performance (COP) in the simulation complies with Chinese Building Design Standard [48]. For mixed-mode ventilation where both mechanical and natural ventilation are used, the thermal comfort thresholds for natural ventilation are determined according to the adaptive thermal comfort model established by de Dear and Brager [50]. Given the fact that not the entire Chinese building stock is suitable for natural ventilation and the difficulty to retrofit existing buildings, here we only used the square footage of one-year newly constructed office building to estimate the NV potential. The cooling energy savings at each city is approximated by multiplying the per-squaremeter saving by the 10-year-averaged square footage of annual newly constructed office building at each city according to the National Bureau of Statistics of the People's Republic of China [51]. Uncertainty analysis on some of the model assumptions is presented in Section 3.3.

\subsection{Carbon emission calculation}

The $\mathrm{CO}_{2}$ emission factor of power grid in each province is derived according to Eq. (9) [52]. 
Table 3

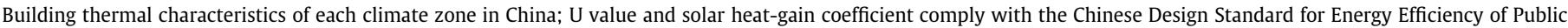
Buildings.

\begin{tabular}{|c|c|c|c|c|c|c|}
\hline Building model & Climate zone & $\begin{array}{l}\text { Roof } \\
\mathrm{U}\left[\mathrm{W} / \mathrm{m}^{2} \cdot \mathrm{K}\right]\end{array}$ & $\begin{array}{l}\text { Wall } \\
\mathrm{U}\left[\mathrm{W} / \mathrm{m}^{2} \cdot \mathrm{K}\right]\end{array}$ & $\begin{array}{l}\text { Ground floor } \\
\mathrm{U}\left[\mathrm{W} / \mathrm{m}^{2} \cdot \mathrm{K}\right]\end{array}$ & $\begin{array}{l}\text { Window } \\
\mathrm{U}\left[\mathrm{W} / \mathrm{m}^{2} \cdot \mathrm{K}\right]\end{array}$ & Window SHGC \\
\hline & Severe cold & 0.25 & 0.35 & 0.25 & 1.76 & 0.68 \\
\hline & Cold & 0.39 & 0.46 & 0.46 & 1.77 & 0.37 \\
\hline & Cold winter hot summer & 0.39 & 0.54 & 0.46 & 2.3 & 0.32 \\
\hline & Warm winter hot summer & 0.44 & 0.72 & 1.32 & 2.4 & 0.2 \\
\hline & Temperate & 0.44 & 0.72 & 1.32 & 2.4 & 0.2 \\
\hline
\end{tabular}

$E F_{P}=\frac{E m_{p}+\sum_{n}\left(E F_{n} \times E_{\text {imp,n,p }}\right)+\sum_{k}\left(E F_{k} \times E_{\text {imp }, k, p}\right)+\left(E F_{\text {Grid, } i} \times E_{i m p, i, p}\right)}{E_{p}+\sum_{n} E_{i m p, n, p}+\sum_{k} E_{i m p, k, p}+E_{\text {imp,i,p }}}$

where $\mathrm{EF}_{\mathrm{p}}$ is $\mathrm{CO}_{2}$ emission factor of province $\mathrm{p}$ in $\mathrm{kgCO}_{2} / \mathrm{kWh}$; $\mathrm{Em}_{\mathrm{p}}$ is direct $\mathrm{CO}_{2}$ emission from electricity generation of province $\mathrm{p}$ given by Eq. (10) in tonCO $\mathrm{CO}_{2} ; \mathrm{EF}_{\mathrm{n}}$ is the average $\mathrm{CO}_{2}$ emission factor of $\mathrm{n}$ provinces that have net electricity export to province $\mathrm{p}$ in $\mathrm{kgCO}_{2} / \mathrm{kWh}$; $\mathrm{E}_{\mathrm{imp}, \mathrm{n}, \mathrm{p}}$ is net electricity export from $\mathrm{n}$ provinces to province $\mathrm{p}$ in $\mathrm{MWh} ; \mathrm{EF}_{\mathrm{k}}$ is the average $\mathrm{CO}_{2}$ emission factor of $\mathrm{k}$ countries that have net electricity export to province $\mathrm{p}$ in $\mathrm{kgCO}_{2} /$ $\mathrm{kWh} ; \mathrm{E}_{\mathrm{imp}, \mathrm{k}, \mathrm{p}}$ is net electricity export from $\mathrm{k}$ countries to province $\mathrm{p}, \mathrm{MWh} ; \mathrm{EF}_{\text {grid,i }}$ is the $\mathrm{CO}_{2}$ emission factor of regional grid $\mathrm{i}$ in $\mathrm{kgCO}_{2} / \mathrm{kWh} ; \mathrm{E}_{\mathrm{p}}$ is the annual electricity generation of province $\mathrm{p}$ in MWh.

$E m_{p}=\sum_{m}\left(F C_{m} \times N C V_{m} \times E F_{m} / 1000\right)$

where $\mathrm{FC}_{\mathrm{m}}$ is the consumption of fossil fuel for electricity generation in province $\mathrm{p}$ in ton or $\mathrm{m}^{3} ; \mathrm{NCV}_{\mathrm{m}}$ is the net calorific value of fossil fuel $\mathrm{m}$ in $\mathrm{GJ} /$ ton or $\mathrm{GJ} / \mathrm{m}^{3}$; $\mathrm{E}_{\mathrm{imp}, \mathrm{i}, \mathrm{p}}$ is net electricity export from regional grid i to province $\mathrm{p}$ in MWh. It is given by Eq. (11).

$E_{\text {imp }, i, p}=\max \left(\left(E_{u, p}-E_{p}-\sum_{n} E_{i m p, n, p}-\sum_{k} E_{i m p, k, p}\right), 0\right)$

where $E_{u, p}$ is the annual electricity consumption of province $p$ in $\mathrm{MWh}$. $\mathrm{EF}_{\mathrm{m}}$ is the $\mathrm{CO}_{2}$ emission factor of fossil fuel $\mathrm{m}$ in tonCO $\mathrm{CO}_{2} / \mathrm{TJ}$ given by Eq. (12).

$E F_{m}=C C_{m} \times O F_{m} \times \frac{44}{12}$

where $\mathrm{CC}_{\mathrm{m}}$ is the carbon content factor of fossil fuel $\mathrm{m}$ in tonC/TJ; $\mathrm{OF}_{\mathrm{m}}$ is the oxidation factor of fossil fuel $\mathrm{m}$ in percentage. The estimations of $\mathrm{CC}_{\mathrm{m}}$ and $\mathrm{OF}_{\mathrm{m}}$ are from our previous studies [53].

\section{Results and discussion}

\subsection{NV hours across China}

NV hours (in the unit of number of hours per year) is defined as when outdoor weather and air quality are suitable for natural ventilation. The temperature and dew point threshold are chosen as when outdoor dry-bulb temperature is below upper threshold of adaptive thermal comfort model and higher than $12.8^{\circ} \mathrm{C}$ (the lowest supply air temperature specified in ASHRAE 55 and fundamental handbook to avoid unpleasant draft to occupants), and the dew point is below $18{ }^{\circ} \mathrm{C}$ for the sake of humidity control $[22,47,50,54-$ 56]. The air quality threshold is chosen at $A Q I=100$, according to China National Ambient Air Quality Standards [45]. Although NV hour does not consider specific information at building scale, it straightforwardly assists architects and energy policy makers in evaluating the regional feasibility of natural ventilation at a large scale without conducting detailed energy simulation. Since NV hour derived from meteorology and air quality data is independent of building types, it can be applied to both office and residential buildings. Building-scale simulation for estimating energy saving is discussed in Section 3.2. Fig. 1 presents the air-pollutionadjusted NV hours with box plot at five climate zones in the year of 2015. The national average NV hours is 2324 (out of $8760 \mathrm{~h} /$ year), with a standard deviation of 778 . Clear differences in NV hour are observed across five climate zones. The Mild climate zone includes cities with the most NV hours. It is the most favorable climate for utilizing natural ventilation mainly due to the suitable outdoor temperature throughout the year. On the other hand, Hot Summer/Cold Winter (HSCW) is the least favorable climate for natural ventilation due the long hot/humid summers and cold/humid winters.

Fig. 2 displays the NV hours considering weather and ambient air pollution data in 76 major cities. The red wedge in the pie chart represents the reduction of NV hours by ambient air pollution. The Southwest region of China includes cities with the greatest NV potential. For instance, Kunming, the capital city of Yunnan Province, has 5913 NV hours. The city is located in the Mild climate zone with an annual average temperature of $15.5^{\circ} \mathrm{C}$ and little variation in temperature throughout the year. The cities with the least NV potential are located in south-central China that fall within hotsummer-cold-winter (HSCW) zones. NV hours are reduced greatly by ambient air pollution in northern China, where there is an enormous coal consumption for power generation [33]. As highlighted in Fig. 2, Zhengzhou, the capital of Henan province, displays the largest loss of NV hours (1655) due to air pollution among studied cities. In contrast, NV hours is reduced little by air pollution in the Northeast region (i.e., Liaoning, Jilin, Heilongjiang) which falls into Severe Cold climate zone, due mainly to the long and extremely cold winter seasons that prohibit natural ventilation regardless of the serious ambient air pollution from coal-firing heat generation. Compared with HSCW zone, the smaller loss in NV hour due to air pollution in the Northeast China does not imply better ambient air quality.

Spring and fall show the largest mean and smallest deviation in NV hours across China (Fig. 3). The national average of NV hours is 794 in spring compared to 207 in winter. In the summer, most cities located in the south of the Yangtze River experience hot and humid weather, which gives little potential for natural ventilation. Cities in the north offered much greater NV potential for cooling energy savings during the summer months. In winter, the northern part of China generally has almost no NV potential due to the cold weather, and the NV hours increase gradually with decreasing latitude from north to south.

\subsection{Energy savings and carbon dioxide reduction}

In this section, the per-square-meter cooling energy savings and carbon reduction potential are estimated using available square 


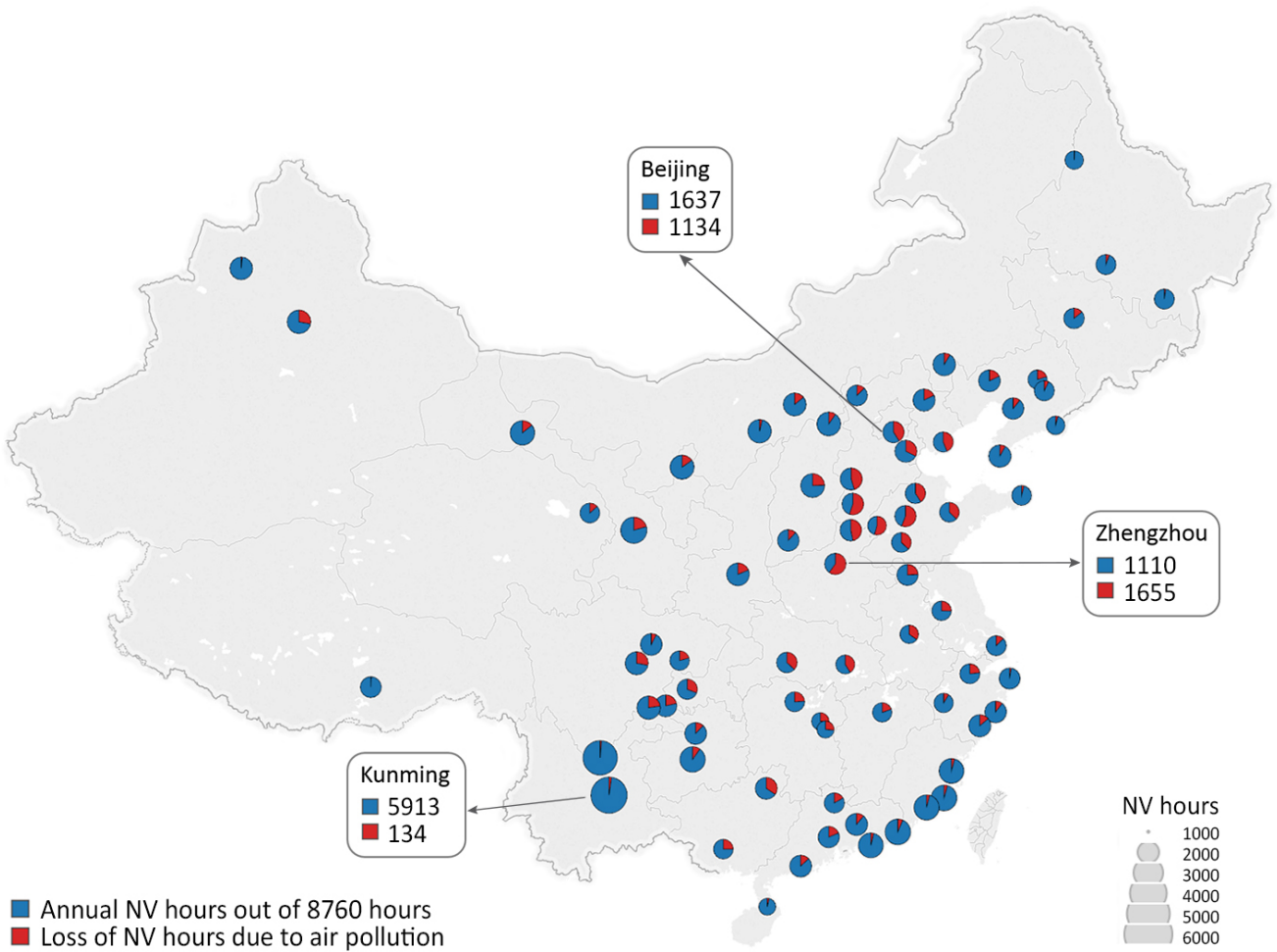

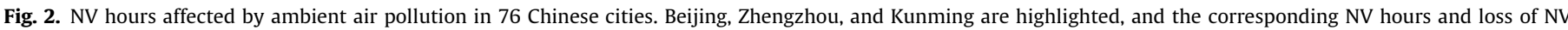
hours due to air pollution are displayed. The unit is in hours per year. The area of the scale bars in the legend of Fig. 2 represents NV hours.

\section{Spring}

\section{Fall}

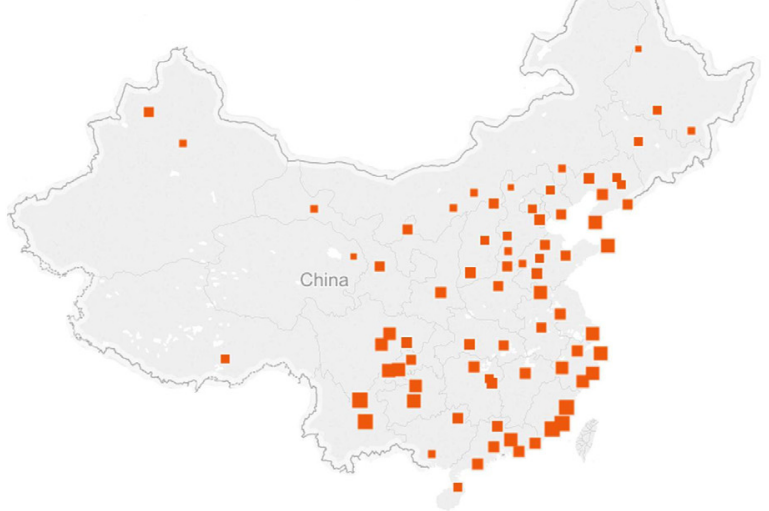

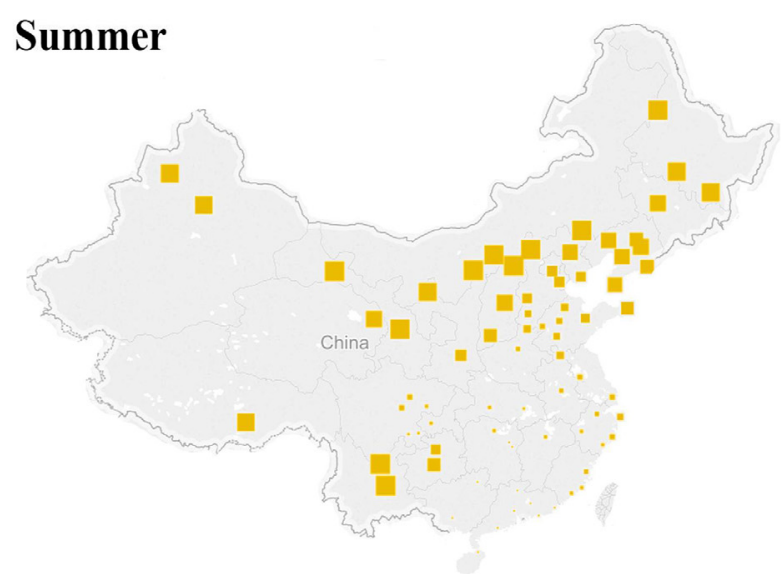

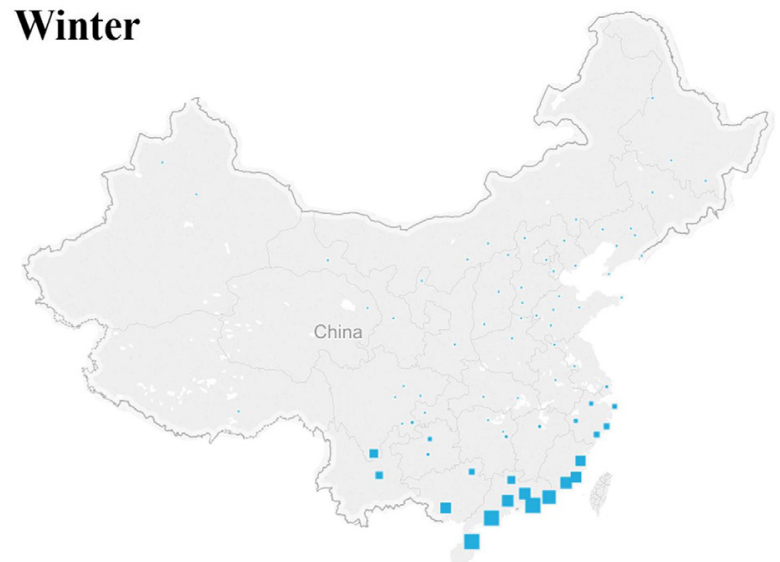

$\underline{\text { Hours }} \quad 100 \quad 500 \quad 1000 \quad 2000$

Fig. 3. Seasonal variation of air-pollution-adjusted NV hours in China. The unit is in hours per year. 
footage data of newly constructed office building in 35 major Chinese cities (see [51]). The main focus of this section is on office buildings where energy saving potentials can be quantified. Residents in China typically ventilate their homes based on personal behavior and thermal comfort preference rather than using fixed set points and schedules. Therefore, there is not enough informa- tion to estimate the natural ventilation potential for residential buildings due to the difficulties of collecting such datasets across major cities in China. Ten-year-averaged annual square footage data of office buildings from 2005 to 2014 is used to eliminate large yearly fluctuation at each city. Fig. 4 shows the per-squaremeter cooling energy consumption and savings potential for office

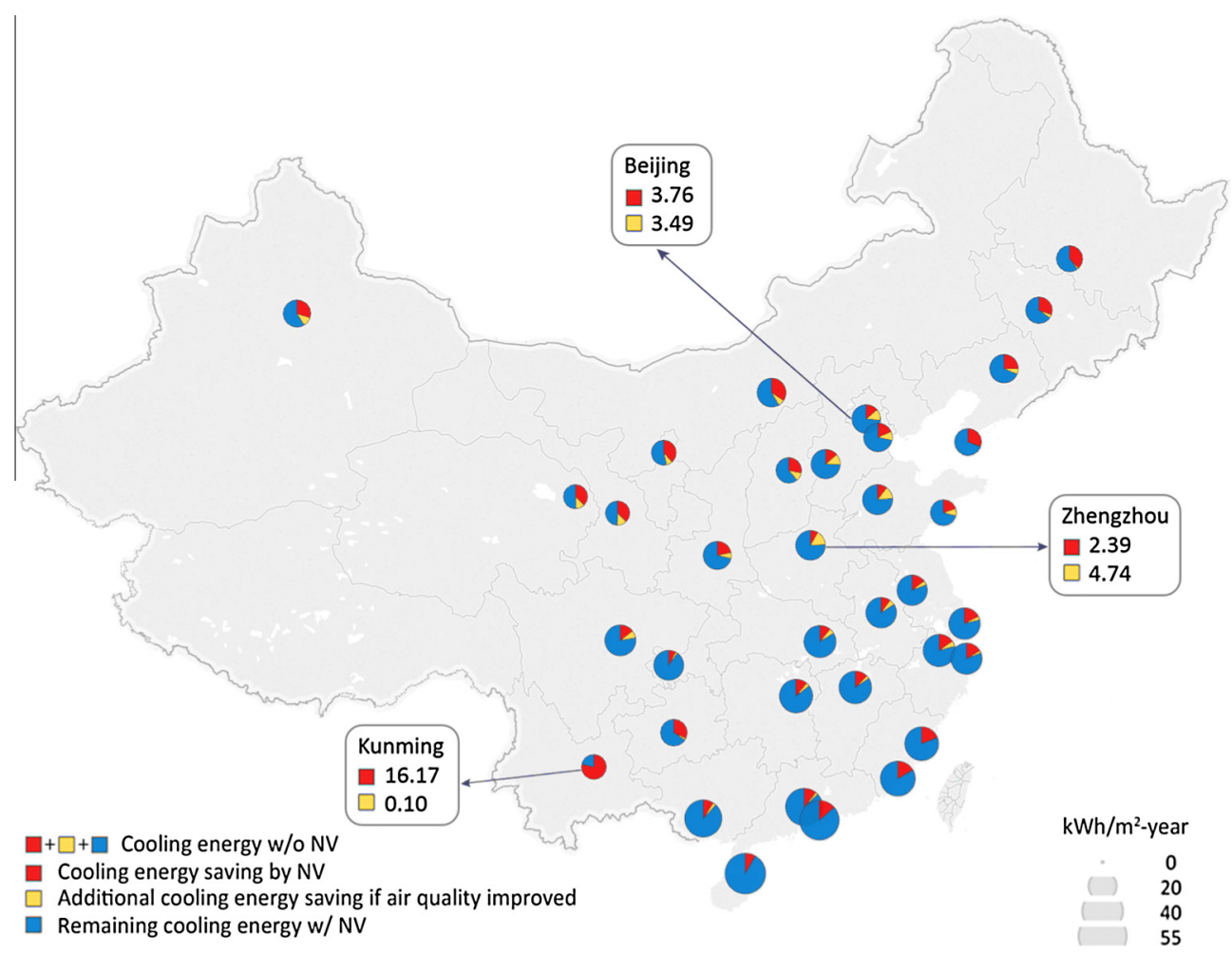

Fig. 4. Per-square-meter office building cooling energy consumption of 35 major Chinese cities in $\mathrm{kWh} / \mathrm{m}^{2}$; the red wedge represents the cooling energy savings potentials by $\mathrm{NV}$. The yellow wedge indicates the additional cooling energy savings if air quality is improved. The blue wedge indicates the remaining cooling energy consumption with NV. Beijing, Chongqing, and Kunming are highlighted, and the corresponding energy savings and additional energy savings if air quality is improved are displayed. (For interpretation of the references to color in this figure legend, the reader is referred to the web version of this article.)

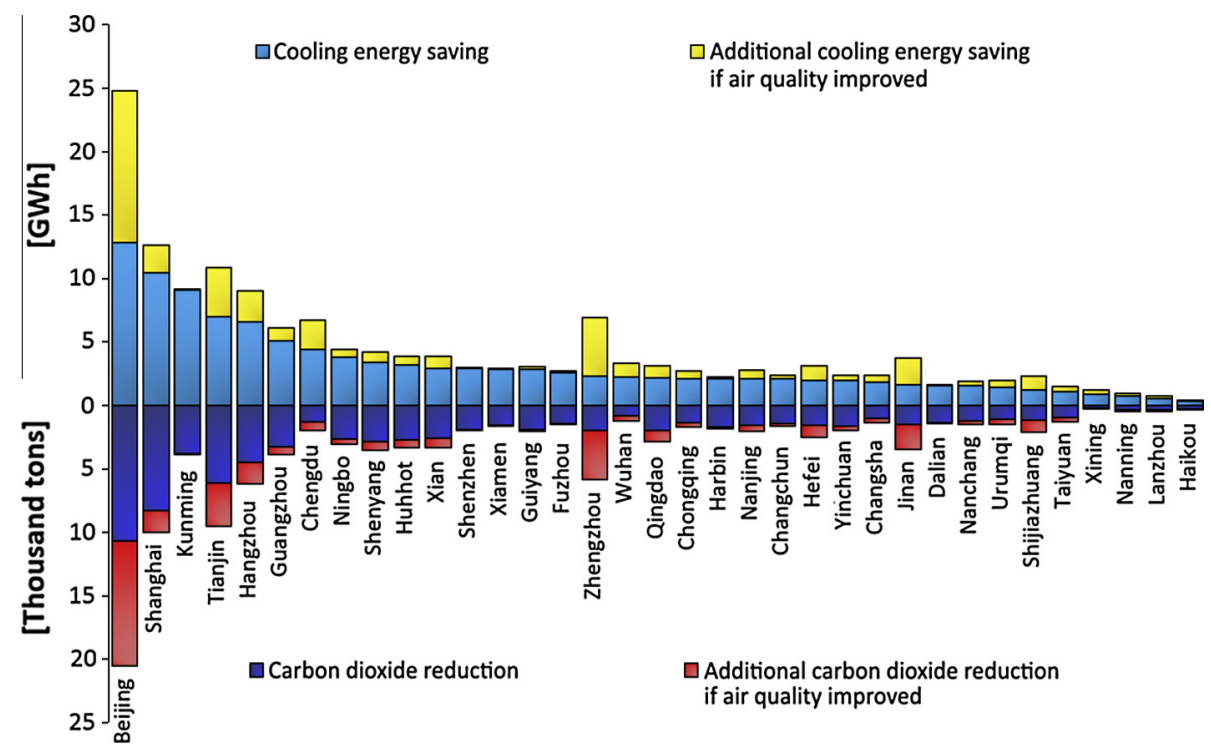

Fig. 5. (Top) energy savings potential and additional cooling energy savings (if air quality is improved) in GWh of 35 major Chinese cities for office buildings ranked from high to low; (Bottom) carbon dioxide reduction potential in thousand tons and the additional cooling energy saving (if air quality is improved) at 35 major Chinese cities for office buildings. 
Table 4

Small, medium and large office buildings for the sensitivity analysis.

\begin{tabular}{lll}
\hline & Number of floors & Floor dimensions \\
\hline Small & 1 Floor & $20 \mathrm{~m} \times 20 \mathrm{~m}$ \\
Medium & 5 Floors & $20 \mathrm{~m} \times 50 \mathrm{~m}$ \\
Large & 10 Floors & $50 \mathrm{~m} \times 50 \mathrm{~m}($ core $20 \mathrm{~m} \times 20 \mathrm{~m})$
\end{tabular}

buildings. The red wedge indicates the potential cooling energy savings by natural ventilation. The yellow wedge indicates the additional cooling energy savings if air quality is improved (i.e., $\mathrm{AQI}$ remains below 100 for the majority of time). The per-squaremeter cooling consumption is generally larger in cities south of the Yangtze River due to the hot weather in the summer. Among 35 studied cities, Kunming is the most favorable for natural ventilation in terms of both weather and ambient air quality. It has a per-square-meter cooling consumption of $20.7 \mathrm{kWh} / \mathrm{m}^{2}$, and $78 \%$ of it could be saved with natural ventilation. The city with the least per-square-meter energy savings potential $\left(2.4 \mathrm{kWh} / \mathrm{m}^{2}\right)$ is Chongqing, which is a major city in southwestern China. Chongqing has hot and humid weather in the summer months, with an average temperature of $27.1{ }^{\circ} \mathrm{C}$ and relative humidity of $79 \%$, which make the city unfavorable for utilizing natural ventilation.

The total savings in cooling energy by city presented in Fig. 5 (Top) considers the total square footage at each city in the estimation. The aggregated energy savings potential of the 35 cities in the year of 2015 is $112 \mathrm{GWh}$, after a loss of $43 \mathrm{GWh}$ due to air pollution. Beijing, the capital city of China, shows limited per-squaremeter savings potential due to the unfavorable weather and air quality for natural ventilation. However, Beijing has the largest square footage of office buildings, and this creates an enormous energy saving opportunity. As shown in Fig. 5, Beijing shows the largest potential of total energy savings ( $25 \mathrm{GWh}$ ) among 35 major cities in China, followed by Shanghai, Kunming, and Tianjin. These cities (except Kunming) are the most economically developed
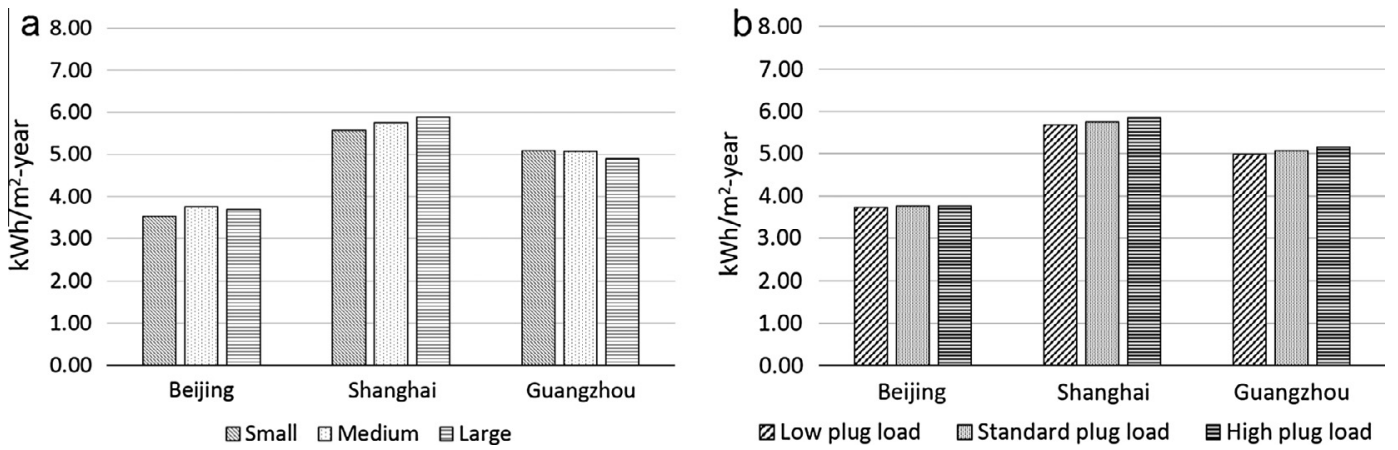

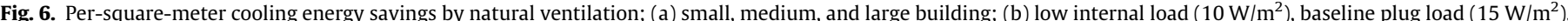
and high internal load $\left(20 \mathrm{~W} / \mathrm{m}^{2}\right)$ in Beijing, Shanghai and Guangzhou.
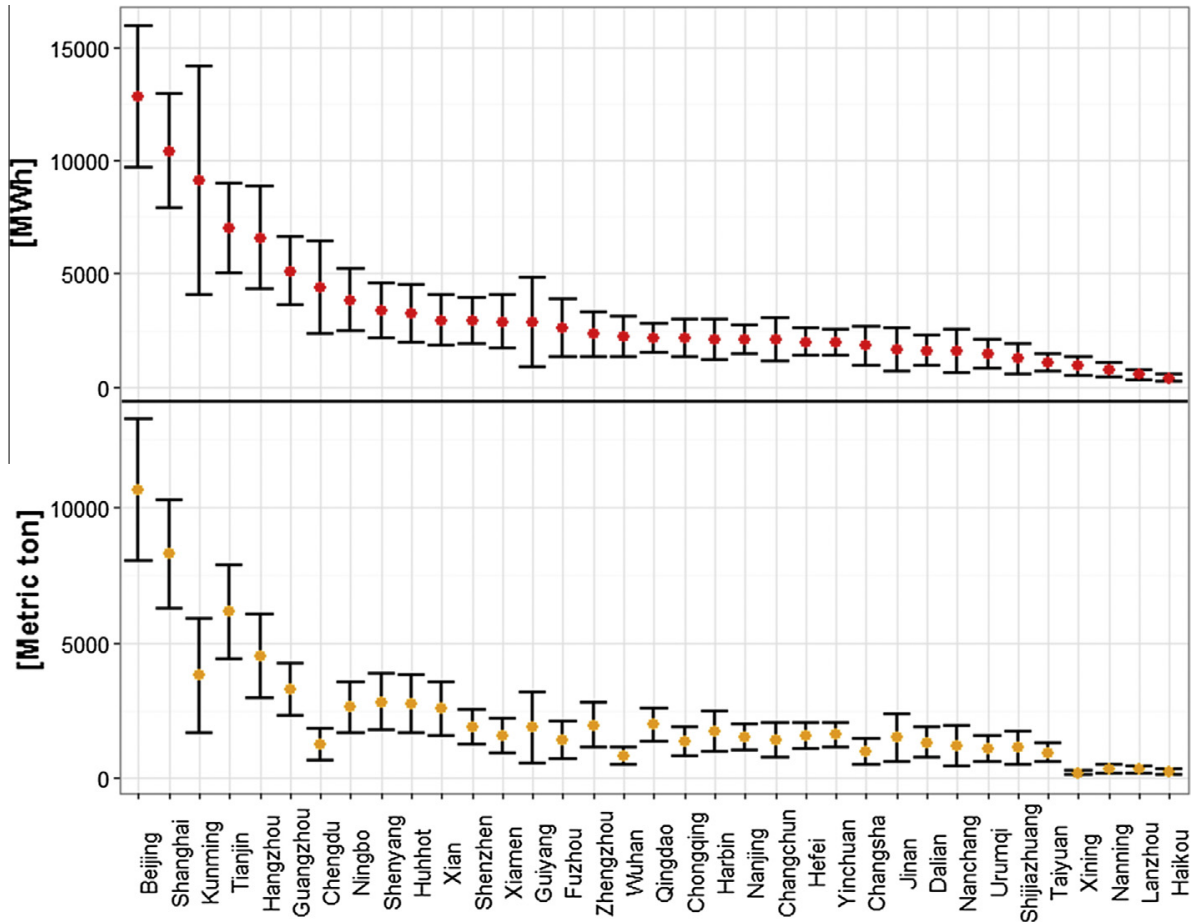

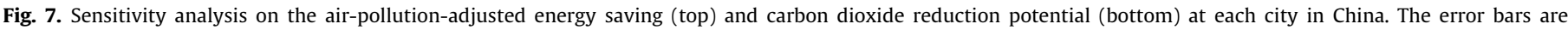
generated using the standard deviation of yearly square footage from the past ten years. 
cities in China, with a large amount of government and private office space, although the per-square-meter savings from them are not among the top. For cities in northern China, savings potential is reduced greatly. For instance, Beijing shows the largest additional energy savings potential of $12 \mathrm{GWh}$ (if air quality is improved), which is equivalent to the sum of the energy savings potential of the bottom ten cities (Fig. 5).

In Fig. 5 (Bottom), the top four cities with the greatest carbon dioxide reduction potential are Beijing, Shanghai, Tianjin, and Hangzhou. The aggregated carbon dioxide reduction potential by utilizing natural ventilation in office buildings at 35 major cities is estimated to be 79,000 tons, with a potential to reach 112,000 tons if AQI remains below 100 for the majority of time. Wuhan and Chengdu are located in the provinces with abundant hydro resources and, therefore, they have a smaller reduction in $\mathrm{CO}_{2}$ emissions per kWh of electricity saved.

\subsection{Sensitivity analysis}

The sensitivity of our methodology is presented in this section. In addition to the baseline five-story medium office, a one-story small office and a ten-story large office are created to examine how the building configurations affect the per-square-meter energy saving (Table 4). Three major cities with large total square footage are selected (Beijing, Shanghai, and Guangzhou in three distinct climate zones). As displayed in Fig. 6a, the per-squaremeter cooling energy savings by natural ventilation from the three office configurations are very close to each other with a variance less than $8 \%$, despite the large difference in building sizes. Therefore, this analysis confirms that it is reasonable to estimate the $\mathrm{NV}$ potential based on the medium office configuration. The second test looked at the effect of plug load, which is varied by $\pm 5 \mathrm{~W} / \mathrm{m}^{2}$ from the baseline $\left(15 \mathrm{~W} / \mathrm{m}^{2}\right)$. As shown in Fig. $6 \mathrm{~b}$, the persquare-meter savings do not vary significantly with load at the same selected cities. This is mainly because when the internal load is less than the baseline load, more cooling energy is required when the indoor temperature is near the lower threshold for natural ventilation, but less cooling energy is required when the indoor temperature is close to the upper threshold. Likewise, the trend of cooling energy usage near the upper and lower threshold is the opposite when the internal load is greater than the baseline load. In addition, due to the large yearly fluctuation in the square footage of newly constructed office building, the third sensitivity study generates error bars for the NV potential at each city based on the standard deviation of the yearly square footage from the past ten years. Fig. 7 displays the error ranges of the airpollution-adjusted energy saving and carbon dioxide reduction potential at each city.

\section{Concluding remarks}

As one of the most important green building features, natural ventilation has become an increasingly attractive design option that provides a comfortable working environment and promising energy savings potential. According to our analysis, ambient air quality and the total square footage at each city must be taken into account when evaluating the reality of NV's total energy savings potential. The aggregated energy savings potential of office buildings at 35 major Chinese cities is $112 \mathrm{GWh}$ in the year of 2015, even after allowing for a $43 \mathrm{GWh}$ loss due to severe air quality problems, especially in North China. Depending on the local weather and air quality of each city, 8-78\% of the cooling energy consumption can be potentially reduced by natural ventilation. Beijing shows a limited per-square-meter savings potential as a result of unfavorable weather and air quality for natural ventila- tion. However, it is the city with the most promising energy saving potential in China ( $25 \mathrm{GWh}$ ) due to its largest total square footage of office buildings. The aggregated carbon dioxide reduction is 79,000 metric tons based on provincial emission factor in China. It can reach 112,000 metric tons if AQI remains below 100 during non-air-pollution-adjusted NV hours, indicating a substantial impact that air pollution has on this issue.

The utilization of natural ventilation creates tremendous energy saving potential, reducing the emissions associated with coal-fired power generation, especially in North China. In addition, the integration of natural ventilation to office buildings would result in lower initial construction costs as a result of downsizing HVAC systems. Contrary to case studies that focus on a particular building or site, the methodology presented here cannot fully take into account neighborhood-scale characteristics such as surroundings, building configurations, and variation of AQI within each city due to limited data availability. However, the purpose of this study is to estimate the NV potential at a national level and therefore contribute to the development of energy and environmental policy in China. Our results demonstrate the co-benefits for NV's energy saving and carbon emission mitigation from reducing outdoor air pollution. While the air pollution is currently a serious environmental issue in China, the human-induced climate change driven by carbon emissions is a global problem facing mankind. Here we show the interactions between local and global challenges. Meanwhile, the natural ventilation potential estimated from this study will be valuable to architects and building operators to better implement different ventilation strategies in order to reduce building energy consumptions based on local climate and air quality conditions throughout China.

\section{Acknowledgement}

Z.T. and Y.C. are grateful for the postdoctoral fellowship from the Center for Green Buildings and Cities (CGBC) at Harvard University. Z.T. greatly appreciates the comments from Prof. Thomas A. Gavin at Cornell University. Z.L. acknowledges the Giorgio Ruffolo fellowship and the support from Italy's Ministry for Environment, Land and Sea.

\section{References}

[1] IMF. World Economic Outlook Database; 2014.

[2] Liu Z, Guan D, Crawford-Brown D, Zhang Q, He K, Liu J. Energy policy: a lowcarbon road map for China. Nature 2013;500:143-5.

[3] Liu Z, Guan D, Moore S, Lee H, Su J, Zhang Q. Climate policy: steps to China's carbon peak. Nature 2015;522:279-81.

[4] Zhang X-P, Cheng X-M. Energy consumption, carbon emissions, and economic growth in China. Ecol Econ 2009;68:2706-12.

[5] Cao B, Zhu Y, Li M, Ouyang Q. Individual and district heating: a comparison of residential heating modes with an analysis of adaptive thermal comfort. Energy Build 2014;78:17-24.

[6] Zhang Y, He C-Q, Tang B-J, Wei Y-M. China's energy consumption in the building sector: a life cycle approach. Energy Build 2015;94:240-51.

[7] TU. Annual report on china building energy efficiency. Beijing: Tsinghua University Building Energy Research Center; 2014. p. 2014.

[8] Chen Y, Samuelson HW, Tong Z. Integrated design workflow and a new tool for urban rainwater management. J Environ Manage 2016;180:45-51.

[9] Chou SK, Chua KJ, Ho JC, Ooi CL. On the study of an energy-efficient greenhouse for heating, cooling and dehumidification applications. Appl Energy 2004;77:355-73.

[10] Chua KJ, Chou SK, Yang WM, Yan J. Achieving better energy-efficient air conditioning - a review of technologies and strategies. Appl Energy 2013;104:87-104.

[11] Cui C, Wu T, Hu M, Weir JD, Li X. Short-term building energy model recommendation system: a meta-learning approach. Appl Energy 2016:172:251-63.

[12] Li X, Wen J, Malkawi A. An operation optimization and decision framework for a building cluster with distributed energy systems. Appl Energy 2016;178:98-109.

[13] Luo M, Cao B, Damiens J, Lin B, Zhu Y. Evaluating thermal comfort in mixedmode buildings: a field study in a subtropical climate. Build Environ 2015;88:46-54. 
[14] Ramponi R, Angelotti A, Blocken B. Energy saving potential of night ventilation: sensitivity to pressure coefficients for different European climates. Appl Energy 2014;123:185-95.

[15] Tong Z, Chen Y, Malkawi A. Defining the influence region in neighborhoodscale CFD simulation for natural ventilation design. Appl Energy 2016. In Revision.

[16] Li X, Wen J. Review of building energy modeling for control and operation. Renew Sust Energ Rev 2014;37:517-37.

[17] Allocca C, Chen Q, Glicksman LR. Design analysis of single-sided natural ventilation. Energy Build 2003;35:785-95.

[18] Artmann N, Manz H, Heiselberg P. Climatic potential for passive cooling of buildings by night-time ventilation in Europe. Appl Energy 2007;84:187-201.

[19] Axley JW. Application of natural ventilation for US commercial buildingsclimate suitability, design strategies \& methods. Gaithersburg, MD, NIST: Modeling Studies; 2001.

[20] Brager GS, de Dear RJ. Thermal adaptation in the built environment: a literature review. Energy Build 1998;27:83-96.

[21] Chen Q. Ventilation performance prediction for buildings: a method overview and recent applications. Build Environ 2009;44:848-58.

[22] Hughes BR, Calautit JK, Ghani SA. The development of commercial wind towers for natural ventilation: a review. Appl Energy 2012;92:606-27.

[23] Malkawi A, Yan B, Chen Y, Tong Z. Predicting thermal and energy performance of mixed-mode ventilation using an integrated simulation approach. Build Simul 2016;9:335-46.

[24] Cardinale N, Micucci M, Ruggiero F. Analysis of energy saving using natural ventilation in a traditional Italian building. Energy Build 2003;35:153-9.

[25] Gratia E, De Herde A. Natural cooling strategies efficiency in an office building with a double-skin façade. Energy Build 2004;36:1139-52.

[26] Oropeza-Perez I, Østergaard PA. Energy saving potential of utilizing natural ventilation under warm conditions - a case study of Mexico. Appl Energy 2014;130:20-32.

[27] Nicol F, Wilson M. The effect of street dimensions and traffic density on the noise level and natural ventilation potential in urban canyons. Energy Build 2004;36:423-34.

[28] Tong Z, Chen Y, Malkawi A, Adamkiewicz G, Spengler JD. Quantifying the impact of traffic-related air pollution on the indoor air quality of a naturally ventilated building. Environ Int 2016;89-90:138-46.

[29] Tong Z, Wang YJ, Patel M, Kinney P, Chrillrud S, Zhang KM. Modeling spatial variations of black carbon particles in an urban highway-building environment. Environ Sci Technol 2012;46:312-9.

[30] Tong Z, Whitlow TH, MacRae PF, Landers AJ, Harada Y. Quantifying the effect of vegetation on near-road air quality using brief campaigns. Environ Pollut 2015;201:141-9.

[31] Tong Z, Whitlow TH, Landers A, Flanner B. A case study of air quality above an urban roof top vegetable farm. Environ Pollut 2016;208(Part A):256-60.

[32] Wu X, Wu Y, Zhang S, Liu H, Fu L, Hao J. Assessment of vehicle emission programs in China during 1998-2013: Achievement, challenges and implications. Environ Pollut 2016;214:556-67.

[33] Chan CK, Yao X. Air pollution in mega cities in China. Atmos Environ $2008 ; 42: 1-42$

[34] Gong P, Liang S, Carlton EJ, Jiang Q, Wu J, Wang L, et al. Urbanisation and health in China. Lancet 2012;379:843-52.

[35] Seaton A, Godden D, MacNee W, Donaldson K. Particulate air pollution and acute health effects. Lancet 1995:345:176-8.
[36] Tong Z, Baldauf RW, Isakov V, Deshmukh P, Max Zhang K. Roadside vegetation barrier designs to mitigate near-road air pollution impacts. Sci Total Environ 2016;541:920-7.

[37] Zhang S, Wu Y, Hu J, Huang R, Zhou Y, Bao X, et al. Can Euro V heavy-duty diesel engines, diesel hybrid and alternative fuel technologies mitigate NOX emissions? New evidence from on-road tests of buses in China. Appl Energy 2014;132:118-26.

[38] Zhang S, Wu Y, Liu H, Huang R, Yang L, Li Z, et al. Real-world fuel consumption and $\mathrm{CO}_{2}$ emissions of urban public buses in Beijing. Appl Energy 2014;113:1645-55.

[39] Zhang Y-L, Cao F. Fine particulate matter (PM2.5) in China at a city level. Sci Rep 2015:5:14884.

[40] Yang L, Zhang G, Li Y, Chen Y. Investigating potential of natural driving forces for ventilation in four major cities in China. Build Environ 2005;40:738-46.

41] Yao R, Li B, Steemers K, Short A. Assessing the natural ventilation cooling potential of office buildings in different climate zones in China. Renew Energy 2009;34:2697-705.

[42] Zhang Y, Wang J, Chen H, Zhang J, Meng Q. Thermal comfort in naturally ventilated buildings in hot-humid area of China. Build Environ 2010;45:2562-70.

[43] GB50178-93. Standard on division of climate zones for buildings. Chinese Construction Industry Publisher; 1993.

[44] China Meteorological Bureau, Climate Information Center, Climate Data Office and Tsinghua University, Department of Building Science and Technology. China Standard Weather Data for Analyzing Building Thermal Conditions. China Building Industry Publishing House; 2005.

[45] GB3095. China national ambient air quality standards. Ministry of Environmental Protection of the People's Republic of China; 2012.

46] Crawley DB, Lawrie LK, Winkelmann FC, Buhl WF, Huang YJ, Pedersen CO, et al EnergyPlus: creating a new-generation building energy simulation program. Energy Build 2001;33:319-31.

[47] ASHRAE. ASHRAE handbook - fundamentals; 2009.

48] PGB50189. Design standard for energy efficiency of public buildings in China. Ministry of Housing and Urban-Rural Development; 2015.

[49] Han F. Comparison of commerical buildings' energy consumption pattern in China and USA Master Thesis. Tsinghua University; 2010.

[50] de Dear RJ, Brager GS. Thermal comfort in naturally ventilated buildings: revisions to ASHRAE Standard 55. Energy Build 2002;34:549-61.

[51] National Bureau of Statistics of the People's Republic of China. China Rea Estate Statistics Yearbooks. China Statistics Press; 2015.

[52] National Development and Reform Commission (NDRC). Provincial carbon emission factor of power grid in China Available at:Available from: http://files. ncsc.org.cn/www/201312/20131221104541539.pdf2013.

[53] Liu Z, Guan D, Wei W, Davis SJ, Ciais P, Bai J, et al. Reduced carbon emission estimates from fossil fuel combustion and cement production in China. Nature 2015;524:335-8.

54] ASHRAE 55, Standard 55, Thermal environmental conditions for human occupancy. American Society of Heating. Refrigerating and Air-Conditioning Engineering; 2004

[55] Rijal HB, Tuohy P, Humphreys MA, Nicol JF, Samuel A, Clarke J. Using results from field surveys to predict the effect of open windows on thermal comfort and energy use in buildings. Energy Build 2007;39:823-36.

[56] Zhu Y, Ouyang Q, Cao B, Zhou X, Yu J. Dynamic thermal environment and thermal comfort. Indoor Air 2016;26:125-37. 